\title{
Intellectual Property Legislation in the Ottoman Era and its Effects on Knowledge Production ${ }^{1}$
}

\author{
By Buket Candan*
}

The development level of all countries is parallel with the importance given to the products of intellectual labor in the information recording media produced by different methods and formats, and the incentives provided to them. In order to promote to promote, supervise and protect the production of these products of intellectual labor that generate the national accumulation of knowledge, and to put them into this service of the users, various legal arrangements have been used from past to present. It is possible to gather these legal arrangements under the heading of intellectual property (IP) legislation. In this study, it is aimed to consider the emergence of the intellectual property legislation in the Ottoman Era and its development from the historical point of view, as well as its contribution and effects on knowledge production. The data within the scope of the research using a historical method, was gathered by using the observation and document scanning techniques.

Keywords: Copyright, Intellectual property rights, Knowledge production, Publications and libraries in the Ottoman Era, Scientific and educational institutions in the Ottoman Era.

Knowledge has always existed since the beginning of humanity, playing an important role for the development of societies. From primitive communities to current modern information society, the knowledge produced at the beginning of each era has gained a fresh dimension, and the importance of knowledge production continues increasingly. The knowledge that was transferred through words and signs in prehistoric times, was turned into letters in different shapes to transfer to the next generations.

The systematic and planned production of the knowledge instead of traditional methods emerged as a result of the great Renaissance Movement which started in Italy in the $14^{\text {th }}$ century and affected Europe in the $15^{\text {th }}$ and $16^{\text {th }}$ centuries. In this rebirth period that caused the end of the Middle Ages (Le Goff 2008: 179), the production and dissemination of knowledge/information were transformed together with all the institutions of the society, from the creativity of the individual to the organisation of a scientific establishment; thus the foundations of modern science were provided. This period had also

\footnotetext{
* Assistant Professor, Cankiri Karatekin University, Turkey.

${ }^{1}$ This article is based on a paper presented in the $3^{\text {rd }}$ International Conference on Turkey and Turkish Studies, 27-30 June 2016, Athens, Greece. This is the original version of the article. Based on ATINER's publication policy (http://www.atiner.gr/docs/Publication_Policy.htm), It has been also published in ATINER's Papers Series (Candan 2016) and in a book consists of selected papers presented at the Conference (Candan 2017) edited by Mert Uydac1.
} 
witnessed the transition from the feudal, theocratic structure to the capitalist, liberal system as the bourgeoisie reinforced its strength in the cities and the emergence of nation-states.

The most important role for the increase in knowledge production and dissemination of thoughts during the Renaissance belonged to the invention and was commonly used of the moveable type printing by Johannes Gutenberg in the $15^{\text {th }}$ century (Lindberg 2014: 35-36). Following the invention of the printing machine, the numbers, importance and sizes of the libraries where the knowledge was produced, collected, maintained, arranged and benefitted together with other scientific and education institutions increased day by day in Europe. Furthermore, some university libraries rivaled the other educational institutions (Burke 2001: 22-23, 56). While the national libraries were established in many countries, the interest in the books and literature increased. The libraries were dedicated to the access of knowledge/information, the increase in literacy, and the development of the knowledge level of humanity. Thus, the libraries gained an important place in science, education and social life as their numbers increased (Bielefield and Cheeseman 1993: 24).

The main reason printing was so popular in Europe was the printing privileges being a kind of publisher's monopoly. These privileges were mainly provided by the administrations which aimed at developing printing in their countries by attracting printing professionals. The ownership rights of the printed books in this era were transferred to the printers and bookshops, as a result of these privileges.

Venice was the first city where the printing privilege was provided in Italy and Europe. When the printing machine was firstly brought to Venice by John of Speyer in 1469, Venice College assured him for five years privileges (Bettig 1996: 16). Besides, first patent law of the world was enacted in Venice in 1474 (Bainbridge 2010: 380; Burke 2001: 153) and the first author privilege was again given in Venice in 1486 to Marcantonio Sabellico for his work, called "the History of Venice".

The printing in England was introduced by a successful merchant capitalist Caxton in 1476 (Bettig 1996: 17; Foster and Shook 1989: 13). Caxton published the first best seller "Canterbury Tales" of Chaucer in the printing machine that was developed by him in 1478. The aim of the early legal regulations in England was to attract the printers and book sellers to England, to improve the book commerce. The law of Richard III in 1483 to promote the book circulation in foreign countries is a good example (Bainbridge 2010: 3334). The succeeding regulations included the printing licenses for the works and work groups, printing patents, and censorship (Bettig 1996: 17). The first printing privilege was given to Royal Clerk Pynson for two years in 1518 (Bainbridge 2010: 34). Cambridge University had the Royal patent for printing in 1534, which was followed by Oxford University in 1586. The first commercial publishing house, Longman, was established in 1724 (Owen 1994: $3)$.

A form of copyright protection existed under the Licence Law in 1643 and provided a permanent protection assurance for the works which were registered 
in the Stationers Company. This protection was justified on the grounds that it was a preventive measure against imitating publications, causing a monopoly in reality. The 1662 amendment of this law added an article, which obliged every single printed work to be deposited both in the Royal Library, and the libraries of all the universities. Hence, the libraries had a chance to have a unique collection, and the courts could refer to the original works in order to distinguish the original works from imitation works, against infringement and counterfeiting (Owen 1994: 3, Bielefield and Cheeseman 1993: 25, Bowker 1886: 5).

The Licensing Act was invalidated in 1694 and it was followed by the first modern copyright law of the world: the Statute of Queen Anne which came into force on $10^{\text {th }}$ of April, 1710. In order to exercise the right to ownership for 21 years following the publication of the work by the owner of the work, it was necessary to be registered by the Stationers Company. Many European countries and the US took this law as the base to form their own copyright laws (Bettig 1996: 23, Owen 1994: 3, Bielefield and Cheeseman 1993: 26, Foster and Shook 1989: 14, Bowker 1886: 6), as the right to be assured for the labour of the authors is the best tool to promote creativity. It was continued in the Statute of Queen Anne to save the copies of the printed works in both the Royal Library and the libraries of all universities.

The changes in England, France and the United States of America on copyright laws during the end of the $18^{\text {th }}$ century and the beginning of the $19^{\text {th }}$ century, together with the technological developments in parallel with the increase in information production in the historical course brought the intellectual property concept into the agenda (Feather 1993: 15). The intellectual property theory developed within the framework of the natural law school provided the acceptance of the rights of the creators coming from the natural law on the intellectual properties and its legal protection. Before long, this approach was also accepted in the field of positive law, with the Laws of Revolution during the 1791 and 1793 after the French Revolution. The representatives of the theory in France were d'Hericourt and Voltaire (Ayiter 1972: 29).

The term "intellectual property" refers to the rights stemming from the products of intellectual labor, such as inventions, literary and artistic works, designs, symbols, names and images used in commerce. Intellectual property rights (IPRs) can be divided into two main categories, namely industrial property and copyright. Although it is difficult to define the border between the categories (May 2006: 36), the prevalent view (WIPO 2016: 2, Bainbridge 2010: 5, Schechter and Thomas 2003: 1), however, is that industrial property includes patents for inventions, trademarks, industrial designs and geographical indications, whereas copyright covers literary works (such as novels, poems and plays), films, music, artistic works (such as drawings, paintings, photographs and sculptures), architectural design and rights related to copyright including those of performing artists in their performances, producers of phonograms in their recordings, and broadcasters in their radio and television programs. 
The aim of the intellectual property rights is to promote and support the protection of knowledge that is produced with human labour. The existence of these rights was definitely recognised at the highest level in the Article 27 of the Universal Declaration of Human Rights (1948). The knowledge-based economy that is mentioned together with the modern information society leans on the creativity and knowledge production, so the protection of intellectual property gains more importance every day. This study aims to emphasize how much the intellectual property legislation was important in the past, as it is important today for the knowledge production and dissemination.

\section{Research Purpose}

The printing machine was only introduced to the Ottoman State after about 300 years after Europe, as a result of the reformation movements. However, it did not have the same effect with Europe in terms of knowledge production. This study aims to consider the emergence and development of the intellectual property rights in the Ottoman Era with a historical perspective to figure out its contribution and effect on knowledge production. Towards this aim; the existing situation for the production knowledge were evaluated as of the $15^{\text {th }}$ century when the first book was printed in the printing machine of Gutenberg within the context of the societal transformations in the Ottomans, and after the establishment of the first Turkish printing house, how the science and education institutions, the publications and libraries changed in particular and how the knowledge/information demand of the Ottoman society changed in general were examined by also considering the developments in Europe.

The hypothesis "due to the insufficiency of the works on intellectual rights in the Ottomans, related legislation could not contribute enough to the knowledge production" that was tested in the research process.

\section{Method}

In the research, the knowledge production in the Ottomans in the period from the beginning of the $15^{\text {th }}$ century to the $20^{\text {th }}$ century, and affecting internal and external factors were examined with historical method on the basis of the development of the intellectual property legislation.

The historical research method is the systematic and objective assessment and synthesis of the available records and documents, in order to reach the facts on past events and to have conclusions (Kaptan 1998: 53). The data obtained from primary and secondary documents, and archives can be used to understand today the basis of past data, and to suggest modern solutions for the future.

The data within the scope of the research was collected by using the document scanning and observation techniques. 


\section{Knowledge Production in the Growth Period}

The Ottoman State structure was shaped intensely under the influence of Turk - Islam traditions besides Persian and Byzantine traditions while it was being transformed from a little emirate to an empire. The economic power and resources were based on the state ownership (Berkes 2016: 26). The function of the state was a public mission in hereditary character. All the power, which was infinite, was assigned to the Sultan. The state affairs were dependent on his individual discretion (Findley 1980: 7). The power of the Sultan was supported with a centralized military, efficient bureaucracy and the state controlled the education system and scientific activities for the preparation of soldiers and civilians to the offices of each level of this structure. In this aspect, it was different than the pre-Renaissance theocratic, feudal European countries (Berkes 2016: 24, 26).

During the rule of Mehmed the Conqueror (1432-1481), the Ottoman State entered into a rapid growth period and there were radical changes in the fields of science and education among others. He provided many madrasas, libraries and a great social complex - külliye- to be built in Istanbul, where he wanted to be the centre of science and education for the Turk and Islam world. In the külliye, each madrasa had its own separate library. Mehmed the Conqueror who tried to increase the scientific activities, attached great importance to the libraries. Therefore, he sent books to those libraries from his personal library (Tekeli and İlkin 1993: 15).

Mehmed the Conqueror had also interest in rational sciences, philosophy and European Renaissance culture. During this era, the curriculum of madrasas were re-arranged to include calculations, geometry, and astronomy more than religious matters (Tekeli and İlkin, 1993: 16). He brought Ali Kuşçu, who was one of the mathematics and astronomy scholars of the era, to Istanbul. Twelve books written by Kuşçu on mathematics and astronomy were taught in these madrasas for a long time (Akyüz 2013: 66). He promoted the works of scientists like Hocazade and Alaeddin Tusi in thei" respective fields and asked them to compare the "the Incoherence of the Philosophers" of Gazali who criticised the philosophers accepting the approach of Aristo to metaphysical events with the response of Ibn Rushd "the Incoherence of the Incoherence". He enabled the geography book of Ptolemy to be translated into Arabic and got a world map to be prepared. Mehmed the Conqueror, who had the lectures from Italian humanist Cyriacus of Ancona and other Italian scientists on Rome and European history during his adolescence, provided the walls of the palace to be decorated with Renaissance style frescos (Kaçar 2015: 374). However, despite the invention in the same era, he had never been interested in the printing machine that was the symbol of the birth of capitalism. Since, this period was also the starting point for the Ottomans fight against capitalism (Tabakoğlu 2015: 307). Book publishing was one of the earliest forms of capitalistic entrepreneurship, and it was the first industrial good to be mass produced (Findley 2016: 11, Anderson 1983: 53). 
The interest in rational sciences had continued for some time after Mehmed the Conqueror, the guardian of science. Molla Lutfi and Sinan Pasha who were among the scientists of the era wrote books on mathematics, astronomy and the classification of sciences (Adivar 2000: 47).

Under the rule of Suleiman the Magnificent (1520-1566), the borders of the empire reached three continents, the largest borders of the state, and Istanbul continued to be the centre of the state. This period was the merger and reorganization period. The Ottoman society was consisting of two main parts. First one is the administrating class of Sultan and the military class, and the other one was the subjects who were administered (Tekeli and İlkin 1993: 4).

The military class consisted of the court, religious experts (mudarris, mufti, kadi), seyfiye (soldiers), and clerks. On the other hand, the subjects could be divided according to the settlement, laws, and religions. The settlement was again divided into two: as settled and semi-settled. The settled subjects might be peasants or urbans. While the peasants were working on the lands having the statue of timar (kind of manor) or a foundation, urban subjects were crafts-men or merchandisers. The semi-settled subjects mainly lived off animal husbandry as migrating clans. Legally, they were divided into free people and slaves. The Muslim people were superior in terms of religion. The Greek-Orthodox people, Armenians, and Jews were minorities (Aksoy 2015: 262, Tekeli and İlkin 1993: 4).

The education was traditional. Higher education was only organised to reproduce the military class (Tekeli and İlkin 1993: 4). There were three types of schools providing formal education: religious schools like primary schools, the madrassas like secondary or pre-higher education schools, and the Enderun Schools (special ottoman schools) at higher education (Kazamias 1966: 37). Towards the end of the $16^{\text {th }}$ century, there was a great increase in the number of madrasas and the libraries serving those madrasas. There were about 150 madrasas only in Istanbul in this era (Baltac1 1994: 2815).

\section{The Emergence of Intellectual Property and Its Development}

Despite the magnificence of the Ottoman Empire at the end of the $16^{\text {th }}$ century, The Germans (during the Habsburg Monarchy) - Ottomans war that started after the death of Sultan Murad III, indicated the insufficiencies of the State in terms of many aspects (Oral 2015: 115, 117). The reformations which the State needed could not be achieved. The decay in the military started. More importantly, despite the rapid developments in Europe in the fields of science and technology, Ottoman science and education institutions could not develop the knowledge production required for advancement. During the long lasting Period of Stagnation, the efforts of many administrators to reverse the situation did not result well. As the Regression Period started, the solutions that were searched within the country during the $17^{\text {th }}$ century were replaced with the renovation searches in Europe in the $18^{\text {th }}$ century. 
During the rule of Sultan Ahmed III (1673-1736), as the Treaty of Passarowitz created a peaceful environment, Grand Vizier Damat Ibrahim Pasha $(1660$ - 1730) sent ambassadors to different countries in order to observe the developments in Europe closely, and to develop mutual relationships. In 1721 when Mehmed Efendi was sent to Paris as the Ambassador, his accompanying son Sait Celebi had the chance to see and get to know the printing machine while he was examining the level of France on science and education. After he turned back to Istanbul, he supported Ibrahim Muteferrika who had worked on printing art and been full of the idea to run a printing house for the establishment of a printing house (Adivar 2000: 167, Lewis 1961: 50). Thus, he provided the printing art to be known by the highest offices of the state and to be owned. As it is known, the printing machine was established and run in different periods by the minorities until that date, but it was not officially recognised and approved.

First the Turkish printing house was established in the Ottoman State in 1727 after about 300 years of the invention of the printing machine in Europe, as a result of the religious permission, Fatwa, stating there was not any concern and the Edict allowing the publication of non-religious books, by Ibrahim Muteferrika (Ayiter 1972: 25, Gerçek, 1939: 52, 57). Despite the existence of great expectations such as knowledge production, dissemination, increase in research and education activities (Gerçek 1939: 50-51), commercial gains of the state and the society among the establishment aims defined by Muteferrika, only 534 books could be published from 1729 when the publication of the first book to 1839 when the Imperial Edict of Gülhane in 110 years (Milli Kütüphane 2002, Appendix). Besides, there was no legal regulation to promote the establishment and running of the new printing houses or the production of new works, unlike Europe, during this period.

There are many reasons to be considered in various resources to explain why the printing house establishment did not meet the expectations in the Ottoman State. The below reasons among others were more effective (Berkes 2016: 58, 61, Çakın 2004: 157, Ersoy 1979 64-65, Binark 1977: 30, Alpay 1976: 30):

- The hindrances of the Ottoman Guild system, which was under state control, to the development of printing;

- Objections of the calligrapher;

- The disturbance in the state which occured due to movements of thought developed under favour of printing

- Technical and materials shortcomings;

- Insufficient organisation of the education system in which the religion was mainly taught but the religious books were banned to be printed;

- Non-realisation of cheap book supply as the raw material of paper was imported with high prices;

- Poor literacy level of public. 
The Imperial Edict of Gulhane (1839) in the first half of the $19^{\text {th }}$ century and the 1856 Reformation Edict did not have any article on printing and publishing. However, the free environment created by the Imperial Edict of Gulhane resulted in the opportunity for the development and institutionalisation of printing. While the number of printing houses was increasing, important steps on the promotion of book writing and translation were taken. The first initiative was provided by the Education Council in 1845. Along with the Regulations to made in this Council, for the copyright and translation of the books to be coursed in Higher Education Institute of Darulfunun, the Encumen-i Daniş (Society of Knowledge) was set up in 1851(Lewis 1961: 431, Encumen-i Daniş Nizamnamesi 1851). In addition to 40 domestic members, there were many foreign members in the Council of which the Establishment Regulations firstly mentioned the intellectual rights in the Ottoman State as an official document (K1lıçoğlu 2013: 31, İskit 2000: 39). The examination hereby had the characteristics of the censorship.

There were also radical transformations in the field of education during the Imperial Edict of Gulhane. In 1857, the Ministry of Education was organised for the first time at such a high ministerial level. The General Education Regulation in 1869 defined the central and local administrative levels of the educational institutions, except for the madrassas and they were classified firstly as primary, secondary and higher education schools together with their programs. As the general administration centre of the education, the Great Education Assembly (Meclis-i Kebir-i Maarif) consisting of scientific and administrative chambers was established. The Scientific Chamber would enable various course books and scientific works to be written, translated and establish relations with European universities and work for the development of Turkish language. The Administrative Chamber, on the other hand, would perform the works on the administration of schools, educational assemblies, libraries, museums, and printing houses together with the personnel affairs of the teachers, their inspection and supervisions (Akyüz 2013: 192, Mahmud C 2001: 59, 92). Thus, the administration and supervision of all the libraries including the Foundation libraries were left to the Ministry of General Education by the Regulation. This Regulation also required the establishment of a library in Darulfunun, of Ottomans that gave four years of higher education and was established in 1863. This library was available for public use on certain days. The aim of the re-organisation in education was to provide opportunities to all levels of society for education and to increase the number of literate people.

The first Printing House Regulation in 1857 (İskit 1939: 846) had the characteristic of a censorship since it stipulated the special permission of respective organs of the state for the printing of all kinds of books, brochures, letters, magazines, and so on. However, the Article eight gave lifetime privilege to the author for the aim of reward and promotion. This article required the printing houses to obtain the permissions of the authors to print.

The Copyright Regulation that was also announced (İskit 1939: 873) on the same date with the Printing House Regulation expanded the author 
privileges in the article eight of the Printing House Regulation. Also, this Regulation removed the printing house privileges (printing house monopoly) in the first article in favour of the authors.

In the era of Sultan Abdulhamid II (1842-1918), the Period of Autocracy starting in 1877 , there was a great reduction in the knowledge production as a result of the establishment of Counsel of Inspection and Examination and the enactment of a new Printing Houses Regulation (İskit 1939: 849) including supervision, censorship and heavy penalties which were followed by new laws.

The first Patent Law of Ottomans was again enacted in the Period of Autocracy in 1879. However, Ottomans were underdeveloped in terms of industrialisation compared to Europe and they could not produce technology but they imported technology, so the enactment of the law was in favour of the countries transferring technology. This law had been valid for more than 100 years until the Decree no: 551 having force of Law was in effect in 1995 (Bülbül and Özbay 2010: 51, Kılıçoğlu 2013: 25).

The environment of liberty following the declaration of the $2^{\text {nd }}$ Constitutionalist Period, enactment of new Printing and Publishing Laws (Matbuat Kanun Layihas1, 1909), removal of the censorship committees against censorship, eliminated all negative effects of the era of Abdulhamid II. The Copyright Law that was enacted in 1910 reinforced these positive developments (Hakk1 Telif Kanun Layihas1, 1910). The Law defining the intellectual and artistic works largely was in force until 1955.

The Ottoman State entered in the World War I and the knowledge production was impacted once again like the rest of the world in 1914. This situation could be observed clearly in the number of publications during these years. The number of works printed from the Imperial Edict of Gülhane to 1914 was twenty thousand. The total number of the works printed from the establishment of the Muteferrika printing machine to the termination of the Ottoman State was 36.992 (Appendix).

\section{Discussion and Conclusion}

The invention and improvement of the moveable type printing by Johannes Gutenberg in the $15^{\text {th }}$ century enabled the produced information to be disseminated broadly. It can be said that the Enlightenment in the $18^{\text {th }}$ century, the Industrial Revolution at the beginning of the $19^{\text {th }}$ century, and the great scientific and technical breakthrough in the $20^{\text {th }}$ century were based on the printing machine. It is another fact that the basic values like democracy and human rights were disseminated and universalised as a result of the printing machine and resulting improvement of publishing houses.

The easy duplication and reproduction of knowledge/information produced in Europe after the mass use of the printing machine brought the matter of the protection of intellectual rights into the agenda and the legal regulations on copyrights were weighted. Together with the technologic developments in parallel with the increase in knowledge production caused the emergence of the 
intellectual property concept as a result of the transformations in copyright laws. Since the knowledge production and dissemination were so much promoted, the number and volume of the libraries also increased like other scientific and education institutions.

The printing machine could be introduced into the Ottoman State after about 300 years from its invention as a result of the reformation movements. However, there was not the same effect with Europe in terms of knowledge production. The reasons put forward were generally technical and materials shortcomings; insufficient organisation of the education system in which the religion was mainly taught but the religious books were banned to be printed; non-realisation of cheap book supply as the raw material of paper was imported with high prices; poor literacy level of public.

Contrary to the reasons given above, the hypothesis "due to the insufficiency of the works on intellectual rights in the Ottomans, related legislation could not contribute enough to knowledge production" was tested in the research process. Also, the development of the intellectual property legislation in the Ottoman State was examined, comparing respective laws in Europe, particularly in England; and it was seen that the hypothesis was supported by the findings obtained as a result of the research.

\section{References}

Adıvar AA (2000) Osmanlı Türklerinde ilim [Science in the Ottoman Turks]. İstanbul: Remzi Kitabevi.

Aksoy M (2015) Türklerde sosyal yap1 [Social structure in the Turk]. In C Öztürk (Ed) Türk tarihi ve kültürü, 255-265. Ankara: Pegem Akademi.

Akyüz Y (2013) Türk eğitim tarihi: M.Ö. 1000-M.S. 2013 [The history of Turkish education: B.C. 1000-A.D. 2013]. Ankara: Pegem Akademi.

Alpay M (1976) Harf devriminin kütüphanelerde yansimast [Reflection of the letter revolution in the library]. İstanbul: İstanbul Üniversitesi.

Anderson B (1983) Imagined communities: Reflections on the origin and spread of nationalism. London: Verso.

Ayiter N (1972) Hukukta fikir ve sanat ürünleri [Intellectual and artistic works in law]. Ankara: Sevinç Matbaası.

Bainbridge DI (2010) Intellectual property. Harlow: Pearson Education Limited.

Baltac1 C (1994) İstanbul medreseleri hakkinda notlar [Notes on the Istanbul madrassas]. Ankara: Türk Tarih Kurumu Basımevi.

Berkes N (2016) Türkiye'de çağdaşlaşma [Modernization in Turkey]. İstanbul: Yap1 Kredi Yayınları.

Bettig RV (1996) Copyrighting culture: The political economy of intellectual property. Colorado: Westview Press.

Bielefield A, Cheeseman L (1993) Libraries \& copyright law. New York: NealSchuman Publishers.

Binark İ (1977) Türkiye'ye matbaanın geç girișinin sosyal, psikolojik sebepleri [Social, psychological reasons for late entry of the printing press in Turkey]. Türk Kütüphaneciliği 26(1): 23-47. 
Bowker RR (1886) Copyright its law and its literature: Being a summary of the principles and law of copyright with especial reference to books. London: Sampson, Low, Marston, Searle \& Rivington.

Burke P (2001) Bilginin toplumsal tarihi [A social history of knowledge: from Gutenberg to Diderot]. İstanbul: Tarih Vakfi Yurt Yayınları.

Bülbül Y, Özbay RD (2010) Sanayi Devrimi'nin tartışmalı bir kurumu olarak patent ve Osmanlı'da İhtira Beratı Kanunu [Patent as an controversial application of the industrial revolution, and Ottoman Ihtira Berati Law]. Marmara Üniversitesi I.I. B.F. Dergisi 28(1): 37-55.

Candan B (2017) Intellectual property legislation in the ottoman era and its effects on knowledge production. In M Uydac1 (Ed), Turkish studies from different perspectives (s. 25-38). Athens: Athens Institute for Education and Research.

Candan B (2016) Intellectual property legislation in the Ottoman Era and its effects on knowledge production. Athens: ATINER's Conference Paper Series, No: TUR2016-2183. https://www.atiner.gr/papers/TUR2016-2183.pdf.

Çakın İ (2004) Müteferrika matbaasının düşündürdükleri ve Avrupa'da basımcılığın etkileri: Gelecek için geçmişi anlamak [Some thoughts on Muteferrika's printing press and effects of printing in Europe]. Bilgi Dünyası 5(2): 153-167.

Encümen-i Daniş Nizamnamesi [Regulations] (1851, 01 Haziran, 449), Takvim-i Vekayi [Official Newspaper].

Ersoy O (1979) Türkiye'ye matbaanın girişi [Introduction of the printing press in Turkey]. Türk Kütüphaneciler Derneği Bülteni, 28(1-2), 59-66.

Feather J (1993) Copyright in developing countries: Necessity or luxury. International Information and Library Review 15(1).

Findley CV (2016) Modern Türkiye tarihi: Islam, milliyetçilik ve modernlik [Turkey, Islam, nationalism, and modernity: A history]. İstanbul: Timaş Yayınları.

Findley CV (1980) Bureaucratic reform in the Ottoman Empire: The sublime Porte, 1789-1922. New Jersey: Princeton University Press.

Foster FH, Shook RL (1989) Patents, copyrights \& trademarks. New York: John Wiley \& Sons Inc.

Gerçek S N (1939). Türk matbaacılı̆̆ I: Müteferrifa Matbaası [Turkish printing]. İstanbul: Maarif Vekaleti.

İskit SR (2000) Türkiye'de neşriyat hareketleri tarihine bir bakış [An overview of the history publications movement in Turkey]. Ankara: Millî Eğitim Bakanlığı.

İskit SR (1939) Türkiye'de matbuat rejimleri [The history of media regimes]. İstanbul: Umum Müdürlüğü.

Kaçar M (2015) Türklerde bilim [Science in the Turk]. In C Öztürk (Ed) Türk tarihi ve kültürü̈, 369-392. Ankara: Pegem Akademi.

Kaptan S (1998) Bilimsel araştırma ve istatistik teknikleri [Scientific research and statistical techniques]. Ankara: Bilim Yayınlar1.

Kazamias AM (1966) Education and the quest for modernity in Turkey. Chicago: The University of Chicago Press.

Kılıçoğlu AM (2013) Sinai haklarla karşılaştırmalı fikri haklar [Comparative intellectual rights, with industrial rights]. Ankara: Turhan Kitabevi.

Le Goff J (2008) Avrupa'nın doğuşu [The birth of Europe]. İstanbul: Literatür Yayınc1lik.

Lewis B (1961) The emergence of modern Turkey. London: Oxford Universty Press.

Lindberg C (2014) Avrupa'da reform tarihi [The European reformations]. İstanbul: İnk1lap Kitabevi. 
Mahmud C N (2001) Maarif-i Umumiye Nezareti tarihçe-i teşkilat ve icraatı: XIX. asır Osmanlı maarif tarihi [The history of Ottoman education]. T Kayaoğlu (Ed). Ankara: Yeni Türkiye Yayınları.

Hakk1 Telif Kanun Layihası [The Copyright Bill] (1910, 10 Mart) Meclis-i Mebusan Zabit Ceridesi, (25 Şubat 1325). Retrieved from http://bit.ly/2o5qWiU. [Accessed 28 May 2016].

Matbuat Kanun Layihas1 [Printing and Publishing Law Bills] (1909, 29 Temmuz) Meclis-i Mebusan Zabit Ceridesi, (14/16 Temmuz 1325). Retrieved from http://bit.ly/2oX1QGT. [Accessed 28 May 2016].

May C (2006) The denial of history : reification, intellectual property rights and the lessons of the past. Capital and Class 88, 33-56.

Milli Kütüphane [National Library of Turkey] (2002) Eski harfli Türkçe basma eserler bibliyografyast (1584-1986) [Turkish bibliography of printed works with old letters]. Ankara: Kültür Bakanlığı Millî Kütüphane Başkanlığı.

Oral E (2015) Osmanl Imparatorluğu [The Ottoman Empire]. In C Öztürk (Ed) Türk tarihi ve kültürü̈, 107-137. Ankara: Pegem Akademi.

Owen L (1994) Selling rights. London: Blueprint.

Schechter RE, Thomas JR (2003) Intellectual property: The law of copyrights, patents and trademarks. USA: Thomson, West Group.

Tabakoğlu A (2015) Türklerde ekonomi [The economy in the Turk]. In C Öztürk (Ed) Türk tarihi ve kültürü, 287-316. Ankara: Pegem Akademi.

Tekeli İ, İlkin S (1993) Osmanlı İmparatorluğu'nda eğitim ve bilgi üretim sisteminin oluşumu ve dönüşümü [The formation and transformation of education and knowledge production systems in the Ottoman Empire]. Ankara: Türk Tarih Kurumu Basimevi.

The Universal Declaration of Human Rights (1948). Retrieved from http://bit.ly/ 1O8f0nS. [Accessed 28 May 2016].

WIPO (2016) What is intellectual property? http://bit.ly/1MRKbGN. [Accessed 27 May 2016]. 


\section{Appendix}

Published Works in the Ottoman Era (1729-1922)

\begin{tabular}{|c|c|c|c|c|c|c|c|}
\hline Year & Number & Year & Number & Year & Number & Year & Number \\
\hline 1729 & 6 & 1730 & 6 & 1731 & 0 & 1732 & 2 \\
\hline 1733 & 1 & 1734 & 3 & 1735 & 0 & 1736 & 1 \\
\hline $1737-1739$ & 0 & 1740 & 6 & 1741 & 1 & 1742 & 3 \\
\hline 1743 & 1 & $\begin{array}{l}1744- \\
1752\end{array}$ & 0 & 1753 & 2 & 1754 & 0 \\
\hline 1755 & 1 & 1756 & 6 & 1757 & 1 & 1758 & 1 \\
\hline $\begin{array}{c}1759- \\
1763\end{array}$ & 0 & 1764 & 2 & $1765-1766$ & 0 & 1767 & 1 \\
\hline 1768 & 4 & 1769 & 1 & $1770-1773$ & 0 & 1774 & 1 \\
\hline 1175 & 0 & 1776 & 2 & 1777 & 2 & $1778-1779$ & 0 \\
\hline 1780 & 2 & 1781 & 1 & 1782 & 4 & 1783 & 6 \\
\hline 1784 & 5 & 1785 & 2 & 1786 & 4 & 1787 & 3 \\
\hline 1788 & 1 & 1789 & 3 & 1790 & 0 & 1791 & 3 \\
\hline 1792 & 1 & 1793 & 1 & 1794 & 5 & 1795 & 5 \\
\hline 1796 & 12 & 1797 & 1 & 1798 & 4 & 1799 & 8 \\
\hline 1800 & 7 & 1801 & 5 & 1802 & 6 & 1803 & 10 \\
\hline 1804 & 12 & 1805 & 11 & 1806 & 10 & 1807 & 13 \\
\hline 1808 & 3 & 1809 & 8 & 1810 & 4 & 1811 & 2 \\
\hline 1812 & 12 & 1813 & 5 & 1814 & 7 & 1815 & 4 \\
\hline 1816 & 13 & 1817 & 12 & 1818 & 10 & 1819 & 16 \\
\hline 1820 & 13 & 1821 & 2 & 1822 & 8 & 1823 & 5 \\
\hline 1824 & 11 & 1825 & 11 & 1826 & 25 & 1827 & 15 \\
\hline 1828 & 24 & 1829 & 25 & 1830 & 20 & 1831 & 26 \\
\hline 1832 & 19 & 1833 & 24 & 1834 & 36 & 1835 & 41 \\
\hline 1836 & 62 & 1837 & 52 & 1838 & 55 & 1839 & 68 \\
\hline 1840 & 83 & 1841 & 86 & 1842 & 65 & 1843 & 53 \\
\hline 1844 & 62 & 1845 & 67 & 1846 & 94 & 1847 & 71 \\
\hline 1848 & 104 & 1849 & 62 & 1850 & 83 & 1851 & 85 \\
\hline 1852 & 73 & 1853 & 119 & 1854 & 73 & 1855 & 73 \\
\hline 1856 & 95 & 1857 & 97 & 1858 & 107 & 1859 & 172 \\
\hline 1860 & 115 & 1861 & 109 & 1862 & 101 & 1863 & 113 \\
\hline 1864 & 163 & 1865 & 142 & 1866 & 120 & 1867 & 157 \\
\hline 1868 & 175 & 1869 & 203 & 1870 & 291 & 1871 & 389 \\
\hline 1872 & 613 & 1873 & 439 & 1874 & 343 & 1875 & 352 \\
\hline 1876 & 337 & 1877 & 253 & 1878 & 148 & 1879 & 209 \\
\hline 1880 & 242 & 1881 & 291 & 1882 & 354 & 1883 & 391 \\
\hline 1884 & 447 & 1885 & 452 & 1886 & 587 & 1887 & 564 \\
\hline 1888 & 587 & 1889 & 592 & 1890 & 763 & 1891 & 816 \\
\hline 1892 & 697 & 1893 & 547 & 1894 & 665 & 1895 & 565 \\
\hline 1896 & 610 & 1897 & 540 & 1898 & 554 & 1899 & 610 \\
\hline 1900 & 499 & 1901 & 439 & 1902 & 402 & 1903 & 347 \\
\hline 1904 & 345 & 1905 & 482 & 1906 & 176 & 1907 & 190 \\
\hline 1908 & 759 & 1909 & 1.131 & 1910 & 1.341 & 1911 & 1.739 \\
\hline 1912 & 1.641 & 1913 & 1.436 & 1914 & 1.629 & 1915 & 1.101 \\
\hline 1916 & 892 & 1917 & 685 & 1918 & 688 & 1919 & 765 \\
\hline 1920 & 619 & 1921 & 512 & 1922 & 877 & TOTAL & 36.902 \\
\hline
\end{tabular}

Source: Milli Kütüphane [National Library of Turkey], 2002. 
